\title{
Insights into the Semantics of Reduplication in English and Arabic
}

\author{
Khaled Mohammed Moqbel Al-Asbahi ${ }^{1}$ \\ ${ }^{1}$ Prince Sattam bin Abdulaziz University, Saudi Arabia \\ Correspondence: Khaled Mohammed Moqbel Al-Asbahi, Prince Sattam bin Abdulaziz University, Saudi Arabia. \\ E-mail:khaledasbahi0@gmail.com,k.alasbahi@pasu.edu.sa
}

Received: October 30, 2019 Accepted: December 29, 2019 Online Published: January 13, 2020

doi:10.5539/ijel.v10n1p384 URL: https://doi.org/10.5539/ijel.v10n1p384

\begin{abstract}
The paper aims to describe and compare the semantics of reduplication in English and Arabic. The paper shows more semantic similarities in reduplication than differences between both languages; although, Arabic reduplication is noted to be semantically more productive than English reduplication. Both languages divide reduplication into full/partial, free/bound, and continuous/discontinuous. Moreover, both languages share the senses of reduplication like; repetition, emphasis, intensity, onomatopoeia, contempt, affection, plurality, non-uniformity, and instability, nonsense, spread out, scatter, movement, contrast, continuity, completion, and lack of control. The semantic connection was developed between most of these concepts, which showed that ambiguity was common between both languages. Both the languages used reduplication in the nursery rhymes, lyrics, games, prayers, second language teaching, children's phonics cartoons, advertisements, tongue twisters, slogans, newspaper headlines, and political and ideological rhetoric. These similarities support the belief of some linguists stating that different languages in the world share a variety of 'universal' semantic features. The study concluded that Arabic reduplication was semantically more productive than English reduplication.
\end{abstract}

Keywords: Arabic reduplication, English reduplication, semantics, arbitrariness of language, universals

\section{Introduction}

In linguistics, the concept of reduplication and systematic repetition is widely recognized (phonological material). Abu Mansour (2015) highlighted the impact of reduplication on the use of verbs, nouns, and adjectives that account for the changed morphological and semantic base of the word. Predominance of reduplication is observed across different languages, and the expected types include prefixing and suffixing. Inkelas (2014) defined reduplication as the doubling of some morphological constitutes (stem, root, word) to attain some morphological objective (p. 114) and restrict to language morphology only. Common examples in English include 'bye-bye', 'fifty-fifty', 'see-saw', 'flip-flop', and 'zig-zag'.

Reduplication is also common in legal English, where phrases consisting of two or more near-synonyms words frequently occur (Lutsiv \& Sabat, 2016). They are usually called 'legal doublets' such as: 'Terms and conditions,' 'null and void,' 'part and parcel,' 'by and between,' 'blind and obligate,' 'law and order,' and 'due and payable' (Espenschied, 2010). Linguists also provide several definitions; for instance, Stageberg (1981) noted that a new word can be constructed by doubling a morpheme, while Spencer and Zwicky (2001) stated that reduplication is a morphological process wherein the root of a lexeme or a part of it is repeated either completely or with a slight change.

Previous studies refer to reduplication as a repetition that leads to construction of a new word (Khan et al., 2016; Inkelas \& Downing, 2015; Jafari \& Biria, 2015). Such repetition usually takes place with a change in a vowel or consonant. Therefore, Katamba (2006) observed reduplication as a process of affixation (more specifically, the addition of a morpheme to the beginning, middle, or end of a root). Ibrahim (1973) considered that duplication of one letter, word, or sentence suggests several linguistic functions.

In the literature, some synonymous terms such as; repetition, duplication, doubling, and cloning are used for reduplication. All these terms involved syntactic processes that either they change one form or lead to inclusion of more than one form (Hall, 1964). Reduplication for various other languages expresses various lexical, syntactic, and morphological functions (Dineen, 1967). In Arabic, it is known by terms such as Al-tikrar (repetition), Al-Itba'a (duplication), Al-Mudha'afah, or Al-tadh'eef (doubling). A similar aspect among the terms, i.e., 'repetition,' the purpose of which is to emphasize a concept, to express a threat, or glorify something 
(Sejelmasy, 1980, p. 476).

Broselow and McCarthy (1983) expanded the concept of reduplication on the theory of "Internal Reduplication" in the late 1980s and early 1990s. Immense focus is placed on the reduplication forms and patterns among different languages, including Arabic. Kallergi (2015) did not present a single example of reduplication in Arabic in his total reduplication (TR) survey, which limits the semantic function of languages for reduplication. Therefore, the present study aims to assess the unexplored semantic function of Arabic prevailing as an unnoticed area. It mainly focused on reduplication concept based on phonological, morphological, syntactical, and semantic processes for different semantic and morphological purposes.

\section{Literature Review}

The literature review highlights that the previous studies on reduplication have been devoted entirely to the phonology, morphology, and syntax of reduplication in English and Arabic. There is a scarcity of research on the semantic aspect of reduplication in both languages. It seems that no study has been devoted to the semantics of reduplication in their different fields in both English and Arabic. This paper aims to contribute to such gaps as it may be the first study in the literature that is devoted to the semantics of reduplication in both languages. It also aims to bring this aspect to the limelight showing the various functions of reduplication in both languages.

\subsection{Review of the Literature of Semantics of Reduplication in Multiple Languages}

Regier (1994) argued that the semantics of reduplication has some elements which are universal to all languages, i.e., a common semantic network with different structures covering different regions. Similarly, Kauffman (2018) argued that languages from most families reflect the richness and uniqueness of language, thoughts, and culture. This is particularly expressed by those who use this form to create plurals, amplify meaning, change verb tenses, or invent words to describe tangible or intangible parts of the world around us (p. 5). Kauffman (2018) consider reduplication as a funny and extremely interesting aspect of languages.

\subsection{Review of the Literature of Semantics in English}

Regier (2000) stated that many languages share certain meanings of reduplication or linguistic doubling. Conceptually based semantic extension and iconicity are the two forces that interplay attributing towards non-arbitrariness. This results in the constitution of a potentially powerful source of non-arbitrariness mapped through the interaction of iconicity and semantic extension between sound and meaning. Similarly, Wang (2003) analyzed the reduplication of such fixed phrases in English as 'first and foremost,' 'sooner or later' and 'part and parcel' using corpus-based approaches, mainly the British National Corpus. The possible relations between two adjacent words were examined, which showed that the association between the two words is genuine when the mutual information is higher. The present study expands on these factors by examining the semantics of English reduplication.

Rubino (2005) argued that reduplicative morphemes could carry many meanings, and in some languages, the same reduplicative morpheme is used to denote quite contrary meanings (p. 19). Reduplication in nouns can be used to form limitations and new words. Reduplicative verbs and adjectives can express various functions, i.e., intensity, conditionality, plurality, reciprocity, transitivity, argument, tense pretense, and aspect. Rubino (2005) added that reduplication could suggest that the agent is careless about an action or is unable to control it by giving many examples from different languages. Moreover, reduplication can also be used in a few languages to mark the inchoative, designating the start of verbal action; while, reduplication can be used to suggest several functions like distribution, limitation, multiplication, and collection with numbers. Inkelas and Downing (2015) surveyed the reduplication involving phrase repetition, reduplication, which is complex from the viewpoint of morphology and reduplication which has no phonological identification.

\subsection{Review of the Literature of Semantics in Arabic}

The analysis of the literature highlights the deficit concerning research on reduplication in Arabic. For instance, Broselow and McCarthy (1983) were the first to present a formal study of reduplication in Arabic and examined reduplication in Arabic verbs as a morphological infixation. The reduplication in bilateral and trilateral Arabic verbs is viewed as a kind of infixation (an internal repetition); although, bilateral reduplication seems to be a suffix. The most detailed treatment of reduplication in spoken Arabic is that of Cowell, where Syrian Arabic reduplication is often connoted as vividness, emphasis, or repetitiveness (p. 25).

The lexical dimension of reduplication is an area of interest in Arabic dialects. Such as; Avram (2011) studied Juba, Turku, Gulf, and Pidgin Arabic dialects; whereas, McCarthy and Prince (1990) and Suçin (2010) examined modern standard Arabic. Igaab (n.d) focused on the Iraqi dialect; while, the Jordanian dialect was analyzed by Anani (2012). Arabs had authored some books on reduplication in Arabic; for instance, Ibn Faris in his book, 
Al-Itba'a and Al-Muzawajah الإتباع والمزاوجة, arranged alphabetically. Al-Suyuti (1506) wrote a summarized and shorter version of Ibn Fasis' book and gave it the title of Al-Elma'a Fi Al-Itba'a الالماع في الإتباع.

Kagan and Qtit (2016) investigated the Arabic diminutive, which can be constructed using the 'fu'ayl' template, such as low quantity and quality, proximity, and smallness in size. Similarly, Mohammad (2012) argued that significance ascribed to reduplication in spoken or written language has remained an unexplored area. There is unawareness about acceptance of a certain collocation in formal language and rejection of the other. Anani (2012) compiled 123 reduplicative words and provided them to 14 Arabic undergraduate students reading a Semantics course at Petra University to recognize which informal pairs are acceptable formally. The results depicted a limited range of collocates for each group of reduplicative verbs, and certain collocations are acceptable; while, others were not.

Alshdaifat (2014) examined the construction of noun derivatives in Arabic and analyzed the prosodic phonology, morphology, syntax, and the semantics of Arabic noun derivatives. Verbs were divided as per their semantic and syntactic characteristics; while, verbs in each group possess common functions of meaning. The study also analyzed various forms of semantic relations in Arabic, such as synonyms, antonyms, hyponym, and polysemy.

Al Aghbari (2018) studied Omani Arabic and argued that there are various reduplicative verbs in this dialect. The verbs reduplicate in two forms that intrigue from the viewpoint of meaning as they acquire a new meaning that is different from that of its root (p. 57). Omani Arabic reduplicative verbs embrace several meanings and functions from pragmatics because they are used as functions of entertainment, advice, and griping. Abu-Mansour (2015) stated that reduplication in Makkan Arabic is employed to make quadrilateral verbs in which the first or the third consonant of the base is repeated. This ultimately helps in the production of a variety of meanings, including pejoration, iteration, and intensity.

\subsection{Review of the Literature of Semantics in English and Arabic}

Studies on reduplication in both English and Arabic usually focus on phonological, morphological, and syntactic aspects (Khalil, 2010). Zainab Kadim Igaab (2015) discussed reduplication from different levels of phonology, morphology, syntax, and semantics to compare reduplication in both languages. The study concluded that there are major differences and similarities between both languages. Semantically, the study sheds light on groups of words and finds out three categories;

- there are reduplications in both languages

- the constituents of the reduplicative word have no meaning

- the whole reduplicative word has no meaning

The present study does not agree with the last category as it believes that the whole word in a language is meaningless. Another study examined reduplication phonologically and semantically as a child-centered contextual tool of teaching language through nursery rhymes, especially at the pre-school stage (Hasan, 2011). The semantic aspects of reduplication include diminution, repetition, intensity, baby register, scattering, contempt, lack of control, lack of specificity, and continuity. The study hypothesized that reduplication refines moral and instill values within the hearts and souls of the children, as depicted through its contextual investigation.

Omer (2012) argued that reduplication is used to get new syntactic or semantic functions. The differences between English and Arabic is that in English, the main functions are "argumentation, contrast, emphasis and intensity"; while, in Arabic the same functions in English are achieved in addition to plurality, exaggeration, and abundance (p. 70).

\section{Methodology}

\subsection{Study Design}

This study is descriptive and contrastive, along with being exploratory and preliminary. The rationale for selecting this research design is based on its efficacy for describing the reduplication practice across different studies effectively. The study describes the semantics of reduplication in English, the semantics of reduplication in Arabic, and the similarities and differences between semantic reduplication in both languages (Figure 1). The researcher has transliterated and translated Arabic data. 


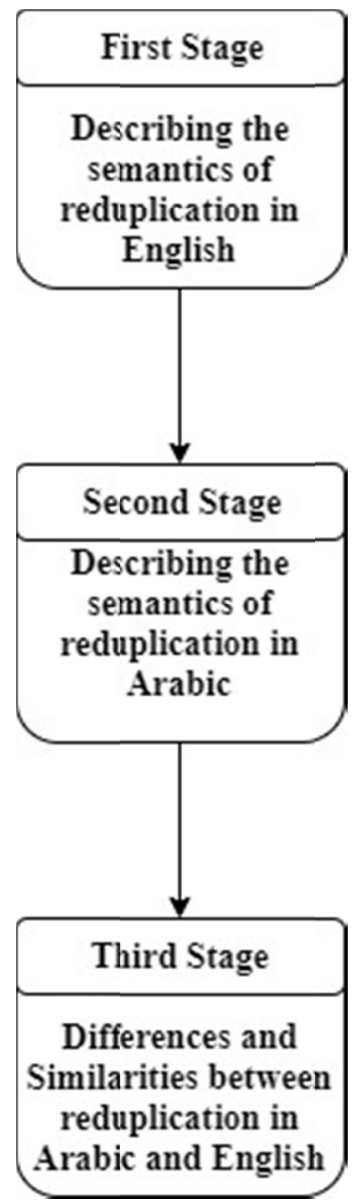

Figure 1. Stages of semantics reduplication

\section{Types of Reduplication in English}

\subsection{Full and Partial Reduplication}

Various studies have reasoned the occurrence of reduplication (Matthews, 1974; O'Grady, Dobrovolsky, \& Katamba, 1997; Matthews, 2007). Either, the whole root (total reduplication) or a part of it is duplicated (partial reduplication).

\subsection{Free and Bound Morphemes Reduplication}

Omer (2012, pp. 71-74) divides reduplication into two groups depending upon the types of morphemes in English; free and bound. Moreover, reduplication is subdivided into continuous reduplication and discontinuous reduplication.

\subsection{Free Morphemes Reduplication}

A free morpheme has its meaning with no affixation. In this sense, Omer (2012) argued that a free morpheme could be added to other morphemes that have a repeated root (either full or partial) for the formation of a new word.

\subsection{Full Reduplication of Free Morphemes}

The meaning and the form of the morpheme is completely duplicated in structure and sense (Ghomeshi et al., 2004; Nadarajan, 2006). An example is 'He has an old, old view.' In English, there is rare appearance of reduplicated bases because they are either borrowed from other languages or used for emphasizing like yatter-yatter.

\subsection{Partial Reduplication of Free Morphemes}

In partial reduplication of free morphemes, only a part of a word is repeated to result in a myriad number of forms. Partial reduplication happens because of the vowel alteration (ablaut) like 'crisscross'; consonant alteration (onset) like 'handy-dandy' in English and 'halal zulal' حلال زلال in Arabic. It also occurs in consonant 
gemination (called in Arabic shaddah), as we find in 'fattit' فتن to mean 'breaking into small pieces.' An example in English is 'reddidh.'

\subsection{Bound Morpheme Reduplication}

The bound morpheme is an affix which cannot stand alone. There are two types of bound morpheme; inflectional and derivational (Hudson, 2000; Spencer \& Zwicky, 2001).

\subsection{Reduplication with Inflectional Morphemes}

Omer (2012) argued that there is no evidence that inflectional affixes in English, commonly recur (p. 72). Several other types of reduplication are shown in English that differ from contrastive reduplication. For instance, the reduplication of baby talks in the form of choo-choo and wee-wee; whereas, depreciative duplication can be presented as table-shamble.

\subsection{Reduplication with Derivational Morphemes}

Reduplication is used derivationally to create new words or to change word classes. This type occurs with the help of affixes (prefixes, infixes, and suffixes). An example of an infix in Arabic is 'katib' (writer) كاتب from 'katab' (wrote) كتب.

\subsection{Continuous vs. Discontinuous Reduplication}

Continuous reduplication refers to copying morphemes in succession; while, discontinuous reduplication means the interruption of reduplicants with additional material (Omer, 2012). The insertion of a small segment between base and reduplicant can result in discontinuous reduplication (Rubino, 2005). On the other hand, continuous reduplication can be referred to as a linguistic form comprising of systematic non-recursive repetition for lexical and morphological purposes. In English, an example of a continuous reduplication is 'sick-sick'; a discontinuous reduplication can be found in the word 'song' as the past participle of the verb 'sing' in the following sentence: 'We have sung a wonderful song.'

\subsection{Reduplication and Word Classes}

According to Igaab (2017), reduplicants create word classes, like verbs, adjectives, and adverbs. For example, reduplicative compounds, which make a verb include 'shilly-shally' (meaning 'to take too much time to decide), 'dilly-dally' (to take too long to do something, go somewhere or make a decision), and 'wiggle-waggle' (to make something move from one side to another or up and down). Examples of reduplicative compounds, which make adjectives include: 'humdrum' (boring and always the same), 'tip-top' (excellent), and 'wishy-washy' (with its two meanings of 'not having clear or firm ideas or beliefs' and 'dark in color'). 'Higgledy-piggledy' (in an untidy way that lacks any order), 'pitter-patter' (with quick light steps or beats), and 'crisscross' (with many straight lines that cross each other) are instances of reduplicative compounds which make an adverb.

\subsection{Semantics of Reduplication in English}

Regier (2000) argued that many languages share different meanings for reduplication (p. 887). However, some of them do not involve the function of duplication: "This non-arbitrariness of the sign may be attributable to the interplay of two forces: iconicity, and conceptually-based semantic extension" (p. 887).

The present study is in agreement with Regier (2000) that reduplication is an exception to this general rule; while, while there is no correspondence between sound and meaning in language (De Saussure, 2011). Its meanings are multi-faceted, including a plurality, intensity, affection, smallness, scattering, lack of control, continuity, and completion, and baby vocabulary (Moravcsik, 1978; Niepokuj, 1991; Regier, 1994). The present study has observed the signal and signification in the language arbitrary. Different linguistics authors such as Firth (1951) and Sapir (1929) showed a correlation between the word form as well as its meaning. However, this does not point towards the word representation as phonetic when making references. On the contrary, Magnus (1998) argued that speech sounds have inherent meanings that provide closer depiction of phoneme-meaning to simplify the reflection of phoneme's articulation.

Regier (2000) observed that regularities between languages regarding reduplication are the result of two factors: the first is the symbolism of sound - a "direct linkage between sound and meaning" (p. 887). Baby talk is one of the themes used in many languages. What is meant in the study by 'baby talk' is the register of language we use to address small children. It reasons that babies often use reduplication extensively in their early stages of speaking' (p. 888). In this case, there is no clear function or correspondence between meaning and sound in the reduplicated form.

Building on the first factor, the second one explains the case. Regier (2000) argued that because meaning may 
spread when reduplication acquires meaning in a certain language, it may also come to acquire other meanings that are connected to it in terms of concept. This is known as 'semantic extension,' which can be repeated several times and be connected to other meanings like a chain (Bybee, Perkins, \& Pagliuca, 1994; Lakoff, 1987; Sweetser, 1990). Regier (2000) explained that the concept of a baby that is explicitly connected to the concept of smallness, which in turn, is connected to 'contempt' (we usually have little concern for small things). This is what is meant by chaining out to other meanings.

It becomes clear by now that "reduplication may mark contempt in some languages because of a trail of semantic extension from the ironically grounded sense of baby, through small, to contempt" (Regier, 2011). The categories that were composed of meanings connected like a chain are what Lakoff calls 'radial categories' (1987). Regier observed that different meanings can have the same conceptual basis and form. For example, the concepts of baby, plurality, and repetition are connected to sound symbolism, especially to the form. This can be clear from Figure 2 where the connection appears between sound and meaning (Regier, 2000). Each one of these meanings (i.e., repetition, baby, and plurality) becomes the base node for a collection of other related notions.

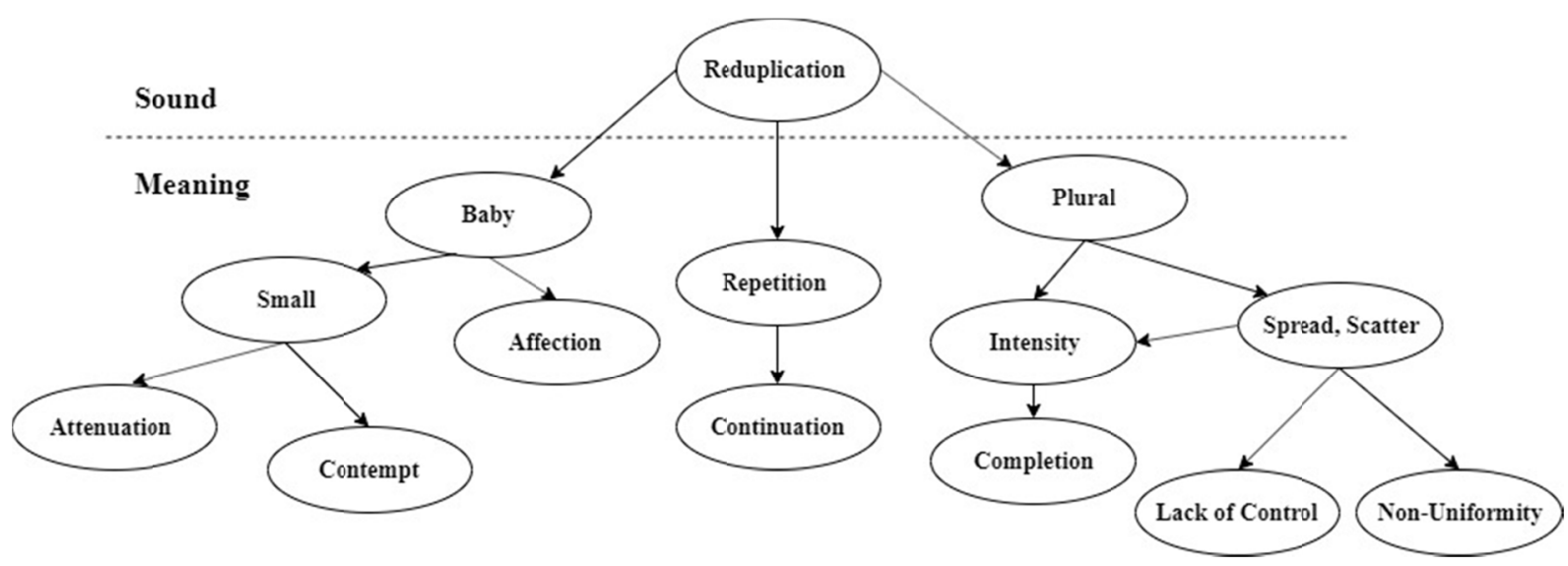

Figure 2. Ionicity and semantic extension interaction

It appears from the above figure that the meanings of reduplication include; completion, plural, intensity, repetition, attenuation, lack of control, continuation, small, scatter, baby, contempt, spread out, affection, and non-uniformity. Such meanings are the basic ones discussed by linguists of reduplication (Moravcsik, 1978; Niepokuj, 1991; Bybee, Perkins, \& Pagliuca, 1994). Regier (2000) concluded that they appear because of this interaction between iconic and conceptual structure. The different meanings of duplication are presented in Table 1. 
Table 1. Reduplication meaning in research

\begin{tabular}{|c|c|c|}
\hline Author & Reduplication & Meaning \\
\hline \multirow[t]{5}{*}{ Omer (2012) } & Intensity & $\begin{array}{l}\text { The intensity of a particular action can be achieved via full reduplication. For example, "Have you } \\
\text { brought the whole luggage with you?" }\end{array}$ \\
\hline & Emphasis & $\begin{array}{l}\text { This frequently happens with full reduplication. The repeated element is employed to distinguish } \\
\text { between 'healthy food' and 'junk food.' The following example is quotable: }\end{array}$ \\
\hline & & A: Would you like to eat food with me? \\
\hline & & B: Do you mean food? \\
\hline & Contrast & $\begin{array}{l}\text { Contrast is expressed here by stressing the first noun. Here is an example from Nadarajan (2006): } \\
\text { 'Is that carrot cheese cake or carrot cake-cake?' }\end{array}$ \\
\hline \multirow[t]{8}{*}{ Regier (2000) } & Repetition & Like that in 'boogie-woogie' \\
\hline & Plurality & $\begin{array}{l}\text { With its several variations like expressing nominal plurality, a plurality of verbal subject, and a } \\
\text { plurality of verbal object. }\end{array}$ \\
\hline & Continuity & Like the meaning of English dilly-dally. \\
\hline & Bird Names: & $\begin{array}{l}\text { Like the meaning of in the English word, 'cuckoo.' The relation between birds and reduplication } \\
\text { can be seen from the fact that birds often make repetitive sounds. }\end{array}$ \\
\hline & Smallness & Like the meaning of English 'nitty-gritty'. \\
\hline & Contempt & $\begin{array}{l}\text { This is related to the concept of smallness. Examples in English include claptrap and hillbilly. } \\
\text { Jurafsky (1993) states that this concept is expressed by the English suffix '-y': while meaning } \\
\text { diminution (e.g., doggy), the suffix '-y' can also suggest derogation or contempt. A similar example } \\
\text { is 'limey,' a derogatory term for an Englishman. }\end{array}$ \\
\hline & Lack of Control & $\begin{array}{l}\text { This can be seen in the English word shelter-skelter. This concept is related to babies who are often } \\
\text { out of control, doing things we do not want them to (Regier). }\end{array}$ \\
\hline & Non-Uniformity & Examples of this concept in English include mish-mash, hodge-podge, knick-knacks, and zig-zag. \\
\hline \multirow[t]{13}{*}{$\begin{array}{l}\text { Ghomeshi } \\
(2004, \text { p. 314) }\end{array}$} & Literal Meaning & $\begin{array}{l}\text { Literal meaning can be understood through an example. For instance, it is a conversation between a } \\
\text { husband and wife who are living apart as they have been recently-separated. }\end{array}$ \\
\hline & & A: Maybe you'd like to come in and have some coffee? \\
\hline & & B: Yeah, I'd like that. \\
\hline & & A: Just COFFEE-coffee, no double meanings \\
\hline & $\begin{array}{l}\text { Prototypical } \\
\text { Meaning for }\end{array}$ & $\begin{array}{l}\text { In it, reduplication is used but with ambiguity. When the same name refers to more than one person } \\
\text { in a conversation, reduplication should be understood to mean the most well-known or important }\end{array}$ \\
\hline & Proper Names: & $\begin{array}{l}\text { word. An example is this: So, did you go to the movie with DAVE-Dave, or with Dave? (The } \\
\text { meaning here is the Dave who is best known to the speaker and hearer). Another usage is that } \\
\text { reduplication functions to compares someone's normal practice with an unusual one. The following } \\
\text { example is quotable: }\end{array}$ \\
\hline & & A: That doesn't sound like Murray. \\
\hline & & B: Remember that he joined that cult, the spiritologists. \\
\hline & & A: MURRAY-Murray!? \\
\hline & & $\begin{array}{l}\text { Further, reduplication can suggest something about the nature of the person we talk about. This can } \\
\text { be done by repeating pronouns: }\end{array}$ \\
\hline & & You see me for a couple of hours out every day, and you think you \\
\hline & & know me? The ME-me? \\
\hline & & $\begin{array}{l}\text { Thus, reduplication and ambiguity are closely related. Obvious terms become ambiguous to one } \\
\text { due to reduplication. For instance, Ghomeshi (2004: } 3150 \text { explains that in the conversation, } A \text { : I've } \\
\text { been invited to go bowling tonight. B: BOWLING-bowling., the repetition of the word 'bowling' } \\
\text { suggests that there is not only one type of bowling which we already know but that there is more } \\
\text { than one type of it. }\end{array}$ \\
\hline
\end{tabular}

The following three usages of reduplication are added by Quirk and Greenbaum (1973), Crystal (2003) and Ghomeshi et al. (2004): (a) the imitation of sounds, as we find in 'ding-dong,' 'bow-wow' and 'tick-tock'; (b) expressing vacillation, nonsense, instability, or insincerity such as 'dilly-dally,' 'wishy-washy,' and 'higgledy-piggledy'; and (c) expressing alternating movements, such as 'flip-flop' and 'see-saw.' Furthermore, Wang (2003) listed the following six categories in which sound symbolism reduplication is usually employed: (1) nursery rhymes, songs, lyrics, and prayer; (2) foreign language learning by (and teaching to) children; (3) tongue twisters, language games, cartoons, and comics; (4) ads, slogans and branding; (5) newspaper headlines; and (6) Political rhetoric.

\section{Types of Reduplication in Arabic}

Reduplication is used in many facets of Arabs' life like; in the Holy Quran and their everyday communication. In the Quran, for instance, following reduplicative words are found: وسوس was-was (whisper), زلزلت zul-zilat 


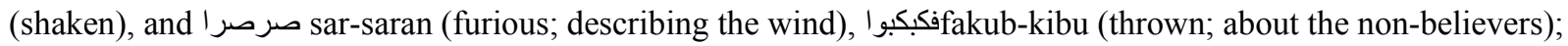
سلاسلا sala-sila (chains), فدمدم زمص fa-dam-dama (destroyed). The reduplicative name,

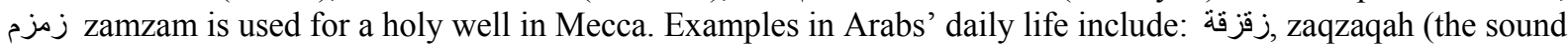

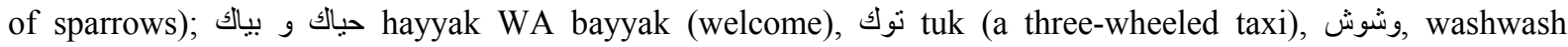
(whisper), هنيئا مريئا hanee'an maree'an (hope you enjoy the food), حلالا زلاك ف halalan-zulalan (halal; legal), and hees-bees (confused). The following two types of reduplication in Arabic are recognized by Igaab (2017):

1) Based on meaning, the second element of reduplication can have sense such as 'atshan natshan' عطشان نطشان ("hungry"). Sometimes it does not have a clear meaning 'saghib laghib' ساغب لاغب, whose first constituent (like "hungry, starving" as Ibn-Faris quoted in Al-Suyoti, 1998) or both constituents are synonymous (like 'xafawat lafawat' meaning "quiet"), or both of them are in their meaning, "badiir afiir' بدير عفير ("sowing, dust").

2) According to Ibn-Faris (qtd in Al-Suyoti, 1998), two types are classified based on whether the two subsequent parts in the reduplicative word share the morphological meter (as in 'rajulan' رجلا رجلا meaning "a man"), or have a different meter (like 'khalid talid' خالد تالد, meaning "immortal"), in the Modern Standard Arabic (MSA)

\subsection{Semantics of Reduplication in Arabic}

Reduplication in Arabic can suggest different meanings, such as emphasis and intensification. Ibrahim (1982) argued that reduplicate form expresses the intensity of an action, or its repetition (p. 82). Thus, 'adda' is "to bite", whereas 'ad'ada' is "to bite repeatedly or in more than one place". Similarly, if "hazza' means "to shake," 'hazhaza' means "to shake more frequently or intensely." Another example of intensity in Arabic reduplication is هيهات هيهات (meaning, 'far,' 'very far'). Second is onomatopoeia, where the Reduplicative words in Arabic are usually quadrilaterals of the type waswasa ('he whispered') and zalzala ('it trembled'). They are often onomatopoetic and refer to movements or animal names.

Holes (2004, p. 105) stated that imitative and synesthetic sound symbolism and onomatopoeia are often expressed in dialect through the usage of reduplicated quadrilaterals which he calls "mimetic of extended or repeated sounds, movements, and actions which occur in the physical world... [there is] very often a direct relationship in this verb type [reduplicated quadrilaterals] between physical phonetic form and semantic function". An example of clear onomatopoeia in Bahraini Arabic Holes provides is 'Tartar' 'to talk aimlessly.'

In Egyptian Arabic, we have 'dashdish' meaning 'to reduce to fragments' from 'dash' 'to mash, pound' (Versteegh, 2009, p. 51). Similar examples can be found in Dowsari Arabic (a dialect spoken in Saudi Arabia, for example [tagtaga], meaning 'he spoke in a funny way.' The third is movement, which examples include laflif, to wrap up and lamlim, to gather up, exhibiting a degree of verbal plurality (Versteegh, 2009). Another meaning is of pluractionality, which is found in Iraqi, Omani, and Zanzibar dialects of Arabic, which express pluractionality and intensification of vigor, speed, magnitude, and extent (Greenberg, 120, 155). Concerning spread out/scatter, Regier (2000) observed this semantic aspect in Palestinian Arabic, as well as in various dialects of Arabic, including Yemeni Arabic and Saudi Arabic.like the many small sprinklable and scatterable foods which have reduplicative names. Pepper (filfil), sesame (simsim), mint (na'na'), and crumbs (fatafit) are some examples.

In the Palestinian word 'kaza-kaza' (whatchamacallit) and the Sudanese word 'sahasaha' (whoever) coming from 'saha' (who), denotes the meaning of lack of specificity in the reduplication for Arabic. According to Ibrahim (1973, p. 83), the duminuation phenomenon is peculiar to Arabic because of the partial duplication. An example is 'ushayishya' عشيشية coming from 'ashya' Anيب (a booklet) from kitab (a book). Last meaning observed is of augmentation, which for the words likes shamlal from shaml شمل (Ibrahim, 1973, p. 85).

\section{Conclusion}

The present study has argued that there is exception in reduplication in English and Arabic. Both languages are more similar than different in terms of the meanings of reduplication. One similarity between them is a division of reduplication into full and partial; free and bound; continuous and discontinuous. The resulted reduplicative word may be composed of two or more constituents; whereas, both languages share similar senses of reduplication: including repetition, emphasis, intensity, onomatopoeia, contempt, affection, plurality, non-uniformity, instability, insincerity, nonsense, spread out, scatter, movement, contrast, continuity, completion, lack of control, and vacillation, signifying a semantic connection between the concepts. Moreover, languages share the existence of ambiguity in reduplication; while; reduplication is used in both languages in the following categories: nursery rhymes, songs, lyrics, prayer, foreign language learning by (and teaching to) children, tongue 
twisters, language games, cartoons, comics, advertisements slogans, branding, newspaper headlines, and political rhetoric.

One difference in the semantics of reduplication between the two languages is that the features of pluractionality, diminution, and augmentation are only available in Arabic. English reduplicants do not express such meanings. Thus, Arabic reduplication seems to be semantically more productive than English reduplication. The findings imply that further focus on the typology of the Arabic linguistic needs to be studied along with English. Lastly, the study also calls for more future research into the semantics of Arabic reduplication, given the abundance of studies on the semantics of English reduplication.

\section{Acknowledgment}

I am grateful to Dr Mohammed Muharram, who assisted me in providing the data. I am also very thankful to all the associated personnel in any reference that contributed to/for this research. Further, this research holds no conflict of interest and is not funded through any source.

\section{References}

Abu-Mansour, M. H. (2015). A Study of Internal Reduplication in Makkan Arabic. Journal of Asian and African Studies, 29-60. Retrieved from https://core.ac.uk/download/pdf/81565249.pdf

Al Aghbari, K. (2018). The Base Does Not Count: A Special Pattern of Reduplicative Verbs in Omani Arabic. International Journal of Arabic Linguistics, 3(1), 57-76. Retrieved from https://revues.imist.ma/index.php?journal=IJAL\&page=article\&op=view\&path $\% 5 \mathrm{~B} \%$

Alshdaifat, A. T. (2014). The Formation of Nominal Derivatives in the Arabic Language with a View to Computational Linguistics. University of Salford. Retrieved from http://usir.salford.ac.uk/id/eprint/33230/1/e-thesis_Abdallah_Alshdaifat_15-12-2014.pdf

Al-Suyuti, A. I. (1506). Al-Elma'a Fi al-Itba'a. Cairo: Al-Khanji Bookshop.

Anani, M. (2012). Acceptability of Arabic Reduplicates. International Journal of Linguistics, 4(4). https://doi.org/10.5296/ijl.v4i4.2416

Avram, A. A. (2011). Pseudo-Reduplication, reduplication and repetition: The case of Arabic-lexified pidgins and creoles. Revue roumaine de linguistique, LVI(3), 225-256.

Broselow, E., \& McCarthy, J. (1983). A theory of internal reduplication. The Linguistic Review, 3, $25-88$. https://doi.org/10.1515/tlir.1983.3.1.25

Bybee, J., Perkins, R., \& Pagliuca, W. (1994). The Evo lution of Grammar: Tense, Aspect, and Modality in the Languages of the World. Chicago: University of Chicago Press.

Crystal, D. (2003). A Dictionary of Linguistics and Phonetics. Oxford: Blackwell Ltd. https://doi.org/10.1108/09504120910969041

De Saussure, F. (2011). Course in general linguistics. Columbia University Press.

Dineen, F. P. (1967). An Introduction to General Linguistics. New York: Holt, Rinehart \& Winston.

Espenschied, L. E. (2010). Eliminate clutter and redundant language $\S$ Eliminate common doublets and triplets. In L. E. Espenschied (Ed.), Contract Drafting: Powerful Prose in Transactional Practice (pp. 164-165). Chicago: American Bar Association. https://doi.org/10.1109/JRPROC.1948.231623

Firth, J. R. (1961). Papers in Linguistics 1934-1951: Repr. Oxford University Press.

Ghomeshi, J., Jackendoff, R., Rosen , N., \& Russell, K. (2004). Contrastive Focus Reduplication in English. Natural Language and Linguistics Theory, 22(2), 307-357. https://doi.org/10.1023/B:NALA.0000015789.98638.f9

Greenberg, J. (1951). The patterning of root morphemes in Semitic. Word, 6, 162-181. https://doi.org/10.1080/00437956.1950.11659378

Hall, R. A. (1964). Introductory Linguistics. New York: Chilton.

Hasan, H. (2011). Reduplication in English and Arabic: A Contrastive Study. ELLS, 3(1), 179-224. Retrieved from

https://www.researchgate.net/publication/281556605_Reduplication_in_English_and_Arabic_A_Contrastiv e_Study

Holes, C. (2004). Modern Arabic: Structures, Functions, and Varieties. Washington, D.C.: Georgetown UP. 
Hudson, G. (2000). Essential Introductory Linguistics. Oxford: Blackwell Puplishers, Inc.

Ibn, F. A. (1947). Al-Itba'a wa Al-Mizawajah. Cairo: Matba'at Al-Sa'adah.

Ibrahim, M. H. (1982). Radical reduplication in arabic. Zeitschrift fur Arabische Linguistik, 9, 82-87. Harrassowitz Verlag. Retrieved March 17, 2019, from https://www.jstor.org/stable/43530966

Igaab, Z. K. (n.d.). Reduplication in English and Arabic: A Contrastive study. Unpublished manuscript. Retrieved from https://www.iasj.net/iasj?func=fulltext\&aId=11911

Inkelas, S. (2014). The interplay of morphology and phonology (Vol. 8). Oxford University Press. https://doi.org/10.1093/acprof:oso/9780199280476.001.0001

Inkelas, S., \& Downing , L. J. (2015). What is Reduplication? Typology and Analysis Part 1/2: The Typology of Reduplication. Language and Linguistics Compass, 9(12), 502-515. https://doi.org/10.1111/lnc3.12166

Jafari, B., \& Biria, R. (2015). The contrastive pragmatic analysis of refusal speech acts in English and Persian fairy tales: A Natural Semantic MetaLanguage (NSM) approach. Elixir Literature, 78, 29622-29628.

Jurafsky, D. (1993). Universals in the semantics of the diminutive. In Proceedings of the Nineteenth Annual Meeting of the Berkeley Linguistics Society. Berkeley: University of California. https://doi.org/10.3765/bls.v19i1.1531

Kagan, O., \& Qtit, M. (2016, January 01). On the Scalar Nature of Arabic Diminutives The Case of the fu'ayl Template. Brill's Journal of Afroasiatic Languages and Linguistics, 8(2). https://doi.org/10.1163/18776930-00802003

Kahn, M. I. (2016). Reduplication in Arabic and Urdu. International Journal of English and Education, 5, 336344.

Kallergi, H. (2015). Reduplication at the word level: The Greek facts in typological perspective (Vol. 17). Walter de Gruyter GmbH \& Co KG. https://doi.org/10.1515/9783110365597

Katamba, F., \& Stonham, J. (2006). Morphology (2nd ed.). New York: Macmillan. https://doi.org/10.1007/978-1-137-11131-9

Kauffman, C. A. (2018). Reduplication Reflects Uniqueness and Innovation in Language, Thought and Culture. Retrieved from http://www.omniglot.com/language/articles/reduplication.htm

Khalil, A. M. (2010). A contrastive grammar of English and Arabic. Jordan Book Centre.

Lakoff, G. (1987). Women, Fire, and Dangerous Things: What Categories Reveal about the Mind. Chicago: University of Chicago Press. https://doi.org/10.7208/chicago/9780226471013.001.0001

Lutsiv, R., \& Sabat, S. (2016). Lexical features of English for business contracts. Doctoral dissertation, Тернопіль, ТНЕУ.

Magnus, M. (1998). What's in a Word: Studies in Phonosemantics. Truman State University Press, Kirksville, MO.

Matthews, P. (1974). Morphology: An Introduction to the Theory of Word-Structure. Cambridge: CUP.

McCarthy, J., \& Prince, A. (1990). Foot and word in Prosodic Morphology: The Arabic broken plural. Natural Language and Linguistic Theory, 8, 209-282. https://doi.org/10.1007/BF00208524

Moravcsik, E. (1978). Reduplicative constructions. In J. H. Greenberg (Ed.), Universals of Human Language (pp. 297-334). Stanford, california: Stanford University Press.

Nadarajan, S. (2006). A Cross-linguistic Study of Reduplication. Arezona Working Papers in SLAT, 13, 39-53. Retrieved from https://tinyurl.com/y3mxfwfz

Niepokuj, M. K. (1991). The historical development of reduplication, with special reference to Indo-European. Berkeley, California, USA: University of California.

O’Grady, W., Dobrovolsky, M., \& Katamba, F. (Eds.). (1997). Contemporary linguistics. St. Martin's.

Omer, H. K. (2012). A morphological Study of Reduplication in English with Reference to Arabic. Journal of Al-Farahidi's Arts, 13, 70-83. Retrieved from https://iasj.net/iasj?func=fulltext\&aId=67827

Oraby, K. K. (n.d.). Exploiting the Presumed Correlation between Sound and Meaning in Teaching Arabic Vocabulary for Non-Arabs.

Quirk, R., \& Greenbaum, S. (1973). A University Grammar of English. London: Longman. 
Regier, T. (1994). A preliminary study of the semantics of reduplication. California: International Computer Science Institute.

Regier, T. (2000). Reduplication and the Arbitrariness of the Sign In Gernsbache (pp. 887-892). Proceedings of the Twentieth Annual Conference of the Cognitive Science Society. Mahwah, NJ: Lawrence Erlbaum Associates.

Rubino, C. (2005). Reduplication: Form, function and distribution. In B. Hurch (Ed.), Studies on reduplication (pp. 11-29). Berlin: Mouton de Gruyter.

Rubino, C. (2005a). Reduplication: Form, function and distribution. Studies on Reduplication, 11-29. https://doi.org/10.1515/9783110911466.11

Sapir, E. (1929). A study in phonetic symbolism. Journal of Experimental Psychology, 12(3), 225. https://doi.org/10.1037/h0070931

Spencer, A. (2001). The Handbook of Morphology. London: Blackwell Publishing. https://doi.org/10.1111/b.9780631226949.2001.x

Stageberg, N. C. (1981). An Introductory English Grammar. New York: Holt, Rinehard and Winston.

Suçin, M. H. (2010). Turkish and Arabic Reduplications in Contrast. Australian Journal of Linguistics, 30(2), 209-226. https://doi.org/10.1080/07268601003678627

Sweetser, E. (1990). From Etymology to Pragmatics: Metaphorical and Cultural Aspects of Semantic Structure. Cambridge, England: Cambridge University Press. https://doi.org/10.1017/CBO9780511620904

Versteegh, K. (2009). Encyclopedia of Arabic Language and Linguistics (Vol. IV). Leiden: Bril.

Wang, S. P. (2003). Mutual information and corpus-based approaches to English reduplication. Retrieved from https://pdfs.semanticscholar.org/1dd9/c72bddfccea76916ae71302bf5de8dd17be7.pdf

\section{Copyrights}

Copyright for this article is retained by the author, with first publication rights granted to the journal.

This is an open-access article distributed under the terms and conditions of the Creative Commons Attribution license (http://creativecommons.org/licenses/by/4.0/). 